\title{
Undesirable and unreturnable individuals: Rethinking the International Criminal Court's human rights obligations towards detained witnesses
}

\author{
Rossella Pulvirenti ${ }^{\star}$ (D) \\ School of Law, Sandra Burslem Building, Manchester Metropolitan University, Lower Ormond St, Manchester M15 6BH \\ Email: r.pulvirenti@mmu.ac.uk.
}

\begin{abstract}
In March 2011, three defence witnesses, who were in detention in the Democratic Republic of Congo (DRC), were transferred to The Hague to testify before the International Criminal Court (ICC) in the trial against Germain Katanga and Mathieu Ngudjolo Chui. Once the witnesses had testified, they were returned to the DRC, even though they feared for their lives, and had lodged an asylum request with the Dutch authorities.

This article argues that the ICC is bound by the principle of non-refoulement: a prohibition on returning or extraditing an individual to a country where there is a real risk, or substantial grounds, they might be subjected to torture or other human rights violations. Like other individuals, ICC witnesses should enjoy protection from refoulement. This conclusion is based on analysis of the relationship between the ICC and international human rights law through two different approaches. The ICC, as an international organization, is obliged to respect the principle of non-refoulement but additional obligations stem from the Rome Statute. Article 21(3) obligates the ICC to interpret and apply the law governing protective measures in conformity with 'internationally recognized' human rights. In concluding that the ICC has not fully acknowledged the extent of witnesses' rights, this article proposes strengthening the role of the witness protection programme to address the evident deficiencies in the ICC's current practice.
\end{abstract}

Keywords: human rights; International Criminal Court; international organization; non-refoulement; witness

\section{Introduction}

This article focuses on the human rights obligations that the ICC owes to detained 'undesirable but unreturnable' ${ }^{1}$ witnesses under the Rome Statute and international human rights law. More specifically, it focuses on the principle of non-refoulement (from the verb 'refouler', which means 'to expel or return'), according to which no one shall be expelled or returned to the frontiers of

${ }^{*}$ The author would like to thank the anonymous reviewers for their comments and to Dr Lynne Chave for her help on an earlier version of the manuscript.

${ }^{1}$ This expression originated from a research project entitled 'Undesirable and Unreturnable?' funded by the Arts and Humanities Research Council (AHRC) grant (2014-2016) and co-ordinated by the Refugee Law Initiative (School of Advanced Study, University of London) and the Center for International Criminal Justice (VU University Amsterdam). In 2017 the topic was at the centre of two special issues: 36(1) of the Refugee Survey Quarterly and 15(1) of the Journal of International Criminal Justice. Since then, the expression has been used to indicated individuals who are suspected of having committed serious crimes but cannot be removed. 
territories where their life or freedom would be threatened on account of their race, religion, nationality, membership of a particular social group or political opinion. ${ }^{2}$

This analysis is inspired by the plight of three defence witnesses ('the DRC Three') in the Katanga and Chui trial. ${ }^{3}$ They were taken from detention in the DRC to The Hague in order to testify before the ICC. Fearing for their lives, the witnesses each filed an asylum request with the Dutch authorities to prevent their return. In doing so, the DRC Three, at that time detained at the ICC prison, found themselves 'caught in a legal limbo' between the parallel regimes of non-refoulement and asylum. ${ }^{4}$ Thus, they were 'undesirable but unreturnable': undesirable from the Dutch perspective because they were suspected of having committed war crimes in the DRC, yet unreturnable because of the real risk they would be subjected to torture. Ultimately, the prisoners' asylum requests were rejected, and they were returned to the DRC. ${ }^{5}$

Despite the time that has elapsed since this incident, there are several reasons why this issue of 'undesirable but unreturnable' witnesses remains topical. Firstly, the ICC has yet to implement any solution for this legal lacuna. Although others assert that it is unlikely the same circumstances repeat, ${ }^{6}$ this view seems questionable since testimony from insider witnesses, such as soldiers, is a common source of exculpatory evidence. ${ }^{7}$ Secondly, any repetition of a similar situation is likely to undermine the ICC's credibility, not only because it might deter witnesses from testifying, ${ }^{8}$ but also, as some authors have argued, because disparity between international criminal law, refugee law, and human rights law might have a detrimental impact on state co-operation. ${ }^{9}$ Thirdly, the modus operandi of the ICC is antithetical to the precedent jurisprudence established by ad hoc tribunals. For example, the return of witnesses by the International

\footnotetext{
${ }^{2}$ Art. 33, Convention Relating to the International Status of Refugees, opened for signature 28 October 1933, LNTS Vol. CLIX No. 3663 (entered into force 22 April 1954).

${ }^{3}$ ICC, Prosecutor v. Katanga and Ngudjolo Chui, Decision on an Amicus Curiae application and on the 'Requête tendant à obtenir présentations des témoins DRC-D02-P-0350, DRC-D02-P-0236, DRC-D02-P-0228 aux autorités nèerlandaises aux fins d'asile' (Arts. 68 and 93(7) of the Statute), ICC-01/04-01/07-3003-tENG, Trial Chamber II, 9 June 2011 ('Decision on an Amicus Curiae').

${ }^{4}$ J. Reijven and J. Van Wijk, 'Caught in Limbo: How Alleged Perpetrators of International Crimes Who Applied for Asylum in the Netherlands Are Affected by a Fundamental System Error in International Law', (2014) 26 International Journal of Refugee Law 248 ('Caught in Limbo'). See also J. Reijven and J. Van Wijk, 'Alleged Perpetrators of Serious Crimes Applying for asylum in the Netherlands: Confidentiality, the interests of Justice and Security', (2015) 15(4) Criminology and Criminal Justice 484.

5. Easterday, 'Witnesses Returned to DRC', International Justice Monitor, 11 July 2014, available at www.ijmonitor.org/ 2014/07/witnesses-returned-to-drc/ (accessed 12 January 2021).

${ }^{6} \mathrm{G}$. Sluiter, 'Shared Responsibility in International Criminal Justice: The ICC and Asylum', (2012) 10 Journal of International Criminal Justice 661, at 16; J. van Wijk, 'When International Criminal Justice Collides with Principles of International Protection: Assessing the Consequences of ICC Witnesses Seeking Asylum, Defendants Being Acquitted and Convicted Being Released', (2013) 26 Leiden Journal of International Law 173, at 183.

${ }^{7}$ For instance, in Bemba several insider witnesses, mostly former soldiers who responded to the orders of President AngeFélix Patassé, were called to testify. See, among others, Witness 178, Prosecutor v. Bemba, (Trial Chamber III) 6 September 2011 (ICC-01/05-01/08-T-154-Red2-ENG); Witness 33, Prosecutor v. Bemba, (Trial Chamber III) 9 September 2011 (ICC-01/ 05-01/08-T-158-Red2-ENG); Witness 32, Prosecutor v. Bemba, (Trial Chamber III) 23 September 2011 (ICC-01/05-01/08T-165-Red2-ENG); Witness 65, Prosecutor v. Bemba, (Trial Chamber III) 11 October 2011 (ICC-01/05-01/08T-168-Red2-ENG). Also, in Gbagbo 11 insider witnesses were called. See, among others, Prosecutor-v-Gbagbo and Blé Goudé, 'Lesser public redacted version of "Public redacted version of Prosecution's consolidated application to conditionally admit the prior recorded statements and related documents of various witnesses under rule 68 and Prosecution's application for the introduction of documentary evidence under paragraph 43 of the directions on the conduct of proceedings relating to the evidence of Witnesses P-0087 and P-0088"' (Trial Chamber I) 8 June 2017 (ICC-02/11-01/15-829-Red2). See also E. Irving, Multi-Actor Human Rights Protection at the International Criminal Court (2020), 166.

${ }^{8}$ B. Moran, 'Rwanda genocide court's stranded men', Aljazeera America, 30 December 2014, available at america.aljazeera. com/articles/2014/12/30/rwanda-ictr-tanzania.html (accessed 31 January 2020).

${ }^{9}$ J. van Wijk and M. Cupido, 'Testifying behind the Bars - Detained Witness and Human Rights Protection', in C. Stahn (ed.), The Law and Practice of the International Criminal Court: A Critical Account of Challenges and Achievements (2015), 1084, at 1086-7; Reijven and van Wijk (2014), supra note 4.
} 
Criminal Tribunal for Rwanda (ICTR) was contingent upon the guarantee of a fair trial, a satisfactory witness protection programme, ${ }^{10}$ and assurance that the death penalty would not be applied. ${ }^{11}$ Finally, with regard to the complex legal backdrop, evaluation of this legal vacuum might have broader implications for other international criminal institutions. For example, no provisions were made for this eventuality in the Statute or linked legal documents of the recently-established Kosovo Specialist Chambers and Specialist Prosecutor's Office, based in The Hague. ${ }^{12}$ Considering that, at the time, the International Criminal Tribunal for the Former Yugoslavia (ICTY) had difficulties ensuring the safety of Kosovan witnesses, ${ }^{13}$ it is possible that some detained witnesses might seek asylum in the Netherlands.

This article adds to existing scholarship on the shared responsibilities of the ICC and its host state, which Sluiter initiated in $2012,{ }^{14}$ and the subsequent body of research that considers the shared duties of the ICC and the Netherlands arising from asylum claims. ${ }^{15}$ Others have sought to reconcile the goals of non-impunity and non-refoulement from a domestic perspective, ${ }^{16}$ considered the fate of those acquitted by the ICC, or served their sentence but cannot return to their country of origin. ${ }^{17}$ Still others have examined the legal and political challenges that 'undesirable and non-removable' aliens pose to the national asylum and immigration frameworks with a specific focus on Australia, Canada, France, Greece, India, the Netherlands, Turkey, and the UK. ${ }^{18}$

This article, however, considers the issue through a broader lens, addressing a literature gap by focusing on implications of the binding force of non-refoulement for the ICC as an international organization (ICC/IO). To date, the human rights obligations of the ICC/IO have been somewhat downplayed in academic literature. Irving partially addressed this issue in two contributions

\footnotetext{
${ }^{10}$ ICTR, Prosecutor v. Hategekimana, Decision on the prosecution's appeal against the decision on referral under rule 11 bis), ICTR-00558RII-bis, Appeals Chambers, 4 December 2008.

${ }^{11}$ Prosecutor v. Uwinkindi, Decision on Prosecutor's Request for Referral to the Republic of Rwanda, Referral Chamber Designated under Rule 11bis, ICTR-01-75-I, 28 June 2011, at 51. See also C. Stahn, 'Libya, the International Criminal Court and Complementarity: A Test for 'Shared Responsibility', (2012) 10(2) Journal of International Criminal Justice, 346; Irving, supra note 7, at 181.

${ }^{12}$ Assembly of Republic of Kosovo, Law on Specialist Chambers And Specialist Prosecutor's Office, Law No.05/L-053, 3 August 2015.

${ }^{13}$ C. Del Ponte, Madame Prosecutor: Confrontations with Humanity's Worst Criminals and the Culture of Impunity (2009).

${ }^{14}$ G. Sluiter, 'Shared Responsibility in International Criminal Justice: The ICC and Asylum', (2012) 10 Journal of International Criminal Justice 661.

${ }^{15}$ See van Wijk, supra note 6, at 173; T. de Boer and M. Zieck, 'ICC Witnesses and Acquitted Suspects Seeking Asylum in the Netherlands: An Overview of the Jurisdictional Battles between the ICC and Its Host State', (2015) 27 International Journal of Refugee Law 573; D. Yabasun and M. Holvoet, 'Seeking Asylum before the International Criminal Court. Another Challenge for a Court in Need of Credibility', (2013) International Criminal Law Review 725, at 744. Van Wijk tried to hypothesize the possible outcomes of the asylum applications. De Boer and Zieck, and Yabasun and Holvoet, explored the issues of asylum requests, the legality of witnesses' detentions, and the implications for ICC co-operation with its member states reaching opposite conclusions. However, they reached diametrically opposite conclusions. While the former argued that the ICC's arguments to delimit its responsibilities towards those witnesses were not convincing, the latter considered that the ICC's efforts to protect them were laudable and that the uneasy attitude of the Netherlands was unfounded.

${ }^{16} \mathrm{G}$. Gilbert, 'Undesirable but Unreturnable: Extradition and Other Forms of Rendition', (2017) 15 Journal of International Criminal Justice 55 (exploring how laws on extradition can be used to avoid the individuals suspected from escaping prosecution); M. Giuffré, 'Deportation with Assurances and Human Rights', (2017), 15 Journal of International Criminal Justice 75 (focusing on diplomatic assurances); J. Rikhof, 'Prosecuting Asylum seekers Who cannot be Removed', (2017) 15 Journal of International Criminal Justice 97 (the possibility for the host state to initiate prosecutions of aliens for crimes committed outside the host state).

${ }^{17} \mathrm{E}$. Irving, 'When International Justice Concludes: Undesirable but Unreturnable Individuals in the Context of the International Criminal Court', (2017) 15 Journal of International Criminal Justice, 115. On this topic, see also J. van Wijk and B. Hola, 'Acquittals in International Criminal Justice: Pyrrhic Victories?', (2017) 30 Leiden Journal of International Law 241; K. J. Heller, 'What Happens to the Acquitted?', (2008) 21 Leiden Journal of International Law 663.

${ }^{18}$ D. J. Cantor et al., 'The Emperor's New Clothing: National Responses to "Undesirable and Unreturnable" Aliens under Asylum and Immigration Law', (2017) 36 Refugee Survey Quarterly 1, at 1-8.
} 
suggesting that the obligation for the ICC must be exclusively based on the duty to protect witnesses under Articles 68 and 21(3) of the Rome Statute, which states that the application and interpretation of law pursuant to this article must be consistent with internationally recognized human rights'. ${ }^{19}$ This article seeks to expand on these findings by using a dual approach, which reflects the dual nature of the ICC as both a judicial entity (ICC/Court) and an international organization (ICC/IO). ${ }^{20}$ It disputes that the ICC is bound by human rights according to both an internal approach (what the Rome Statute imposes) and an external perspective (what general international law sets for it). As a result, on the one hand, it agrees that Article 68 should be interpreted in light of this Article 21(3) requirement. On the other hand, this article broadens the scope of the human rights obligations by exploring the relationship between international human rights law and the ICC/IO. Although human rights obligations are primarily imposed on states, ${ }^{21}$ the $\mathrm{ICC} / \mathrm{IO}$ is also bound to respect certain sources of human rights law, such as customary law. ${ }^{22}$ In the literature, the wider scope of general human rights obligations is mentioned by de Boer and Zieck, who do not mention the dual nature of the ICC, do not fully engage with the argument that the ICC is an international organization and, thus, do not analyse this argument's implications. ${ }^{23}$ Following this human rights analysis, the present article adds another original element suggesting a different threshold to frame the obligations of the ICC/IO toward witnesses. Irving uses an ill-defined threshold, according to which the ICC has an 'obligation to protect witnesses applied to all forms of risk that the witness might face, as long as it was not patently unconnected to their involvement with the Court'. ${ }^{24}$ Conversely, this article suggests that beyond the obligations the ICC/Court might have towards witnesses, the ICC/IO has, as an entity that supports judicial activity, a set of obligations towards the DRC Three as human beings. The article argues that the ICC/IO should rely on the well-established due diligence principle that obliges the duty holder to take all reasonable steps to fulfil individuals' rights. Finally, this article reaches different conclusions and advances different solutions from existing scholarship. While part of the scholarship argues that the solution is to rely on the shared responsibility between the ICC and its host state, this article agrees with Irving on using Article 68 of the Rome Statute. However, it disagrees with the type of proposed measures, the level of granted protection, how to implement these measures in practice, and the solution for possible state non-compliance. ${ }^{25}$ Indeed, given that the complexity of the ICC's legal framework suggests that the ICC is 'like a giant without arms and legs [which] needs artificial limbs to walk and work', ${ }^{26}$ this article concludes that the ICC should not exclude the possibility to rely upon states co-operation to implement the protection of those witnesses from refoulement. In conclusion, in case of non-compliance, the ICC should resort to the use of Article 87(7) of the Rome Statute referring the matter to the Assembly of States Parties (ASP).

The article adopts the following structure. Section 2 outlines the factual background of the DRC Three case, while Section 3 assesses the human rights obligations of the ICC derived from its

\footnotetext{
${ }^{19}$ E. Irving, 'Protecting Witnesses at the International Criminal Court from Refoulement', (2014) 12 Journal of International Criminal Justice 1141. See Irving, supra note 7.

${ }^{20}$ Independent Expert Review of the International Criminal Court and the Rome Statute System - Final Report, 30 September 2020, at 12, available at asp.icc-cpi.int/iccdocs/asp_docs/ASP19/IER-Final-Report-ENG.pdf (accessed 1 February 2020).

${ }^{21} \mathrm{~K}$. Zeegers, International Criminal Tribunals and Human Rights Law: Adherence and Contextualization (2016), at 1; F. Mégret, 'Beyond Fairness: Understanding the Determinants of International Criminal Procedure', (2009) 14 UCLA Journal of International Law and Foreign Affairs 37, at 44.

${ }^{22}$ See Section 3.2 .

${ }^{23}$ T. de Boer and M. Zieck, 'ICC Witnesses and Acquitted Suspects Seeking Asylum in the Netherlands: An Overview of the Jurisdictional Battles between the ICC and Its Host State', (2015) 27 International Journal of Refugee Law 573, $758,603$.

${ }^{24}$ Irving, supra note 7 , at 168.

${ }^{25}$ Ibid.

${ }^{26} \mathrm{~A}$. Cassese, 'On the current trends towards Criminal Prosecution and Punishment of Breaches of International Humanitarian Law', (1998) 9 European Journal of International Law 1, at 13.
} 
Statute and international human rights law. Based on a case law analysis of risks witnesses face, it proposes that a narrow interpretation of protective measures under Article 68 is inconsistent with Article 21(3). It also establishes that the ICC has an autonomous responsibility to respect the obligation of non-refoulement derived from international customary law. Section 4 evaluates the merits of possible solutions and Section 5 concludes that it is necessary to improve witness protection to resolve this impasse.

\section{The case of the DRC Three: A closer look at the facts and issues}

The three Congolese prisoners, the 'DRC Three', were suspected of treason and of causing the deaths of seven UN peacekeepers in the DRC, resulting in their five-year imprisonment in Kinshasa without any formal charges. ${ }^{27}$ In 2011, the three were transferred from the DRC to the ICC Detention Centre in The Hague. The transfer was made so that the DRC Three could testify for the defence before the ICC's Trial Chamber II in Prosecutor v. Katanga and Ngudjolo Chui. ${ }^{28}$ Their testimony would implicate the then president of the DRC, President Kabila (who was standing for re-election at the time), in the Ituri massacre.

Based upon Article 93(7)(b) of the Rome Statute, ${ }^{29}$ the DRC Three should have been returned to the DRC without delay once their testimony was complete. However, the Duty Counsel, who was appointed by the Victims and Witnesses Unit (VWU) to represent their interests, requested that their return to the DRC be suspended..$^{30} \mathrm{He}$ argued that their testimonies placed their lives at risk of the Congolese authorities because they were political opponents. ${ }^{31}$ The VWU undertook a risk assessment, but concluded that under the rules governing protective measures (Article 87 of the Rules of Procedure and Evidence (RPE)), they only had a mandate to evaluate the risk which a witness might face as a direct result of their testimony. ${ }^{32}$ Accordingly, the Court concluded that the DRC Three's testimony had not resulted in any significantly increased risk which should delay their return to the DRC, ${ }^{33}$ although it did instruct the VWU to maintain contact following their return, and to ensure their safety and general detention conditions. ${ }^{34}$

The Duty Counsel was dissatisfied with this decision. Noting that ordinary protective measures under Article 87 of the RPE, which were designed for those at liberty, had a limited mandate, he argued that the special protective measures envisaged by Article 88(1) RPE were appropriate. He submitted that the most effective protective measure would be for the Chamber to facilitate the witnesses' asylum claim in The Netherlands. ${ }^{35}$ The ICC agreed to a temporary suspension while the asylum applications were considered, since immediate return to the DRC would thwart the asylum claim, and thus deprive them of the right to an effective remedy. However, the

\footnotetext{
${ }^{27}$ ICC, Prosecutor v. Katanga and Ngudjolo Chui, Order to provide further assurances regarding the security of DRC-D02P-0236, DRC-D02-P-0228 and DRC-D02-P-0350, ICC-01/04-01/07-2952, Trial Chamber II, 24 May 2011, at 8 ('Order on further assurances'). On pre-trial detention see C. Fehr, 'Domestic Detention under Article 78(2) of the ICC Statute', (2017) 15 Journal of International Criminal Justice 31.

${ }^{28}$ Decision on an Amicus Curiae, supra note 3.

${ }^{29}$ ICC, Prosecutor v. Katanga and Ngudjolo Chui, Decision on the Urgent Request for Convening a Status Conference on the Detention of Witnesses DRC-D02-P-0236, DRC-D02-P-0228, and DRC-D02-P-035, ICC-01/04-01/07-3254, Trial Chamber II, 1 March 2012, at 17-21; ICC, Prosecutor v. Katanga and Ngudjolo Chui, Public Document Order on the implementation of the cooperation agreement between the Court and the Democratic Republic of the Congo concluded pursuant article 93 (7) of the Statute', ICC-01/04-02/12-A, Appeals Chamber, 20 January 2014.

${ }^{30}$ Decision on an Amicus Curiae, supra note 3, at 27-8.

${ }^{31}$ Ibid., at 30 .

${ }^{32}$ Order on further assurances, supra note 27 , at 26.

${ }^{33}$ Ibid., at 32 .

${ }^{34}$ Ibid. See also ICC, Prosecutor v. Katanga and Ngudjolo Chui, Observations des témoins DRC-D02-P-0236, DRC-D02P-0228 et DRC-D02-P-0350 sur l'Ordre de fournir des assurances supplémentaires concernant la sécurité de DRC-D02P-0236, DRC-D02-P-0228 et DRC-D02-P-0350, ICC-01/04-01/07-3017, Trial Chamber II, 14 June 2011, at 20.

${ }^{35}$ Decision on an Amicus Curiae, supra note 3, at 1-16.
} 
Chamber held that it was unable to halt the return indefinitely based upon an obligation of nonrefoulement, even though this decision led to the distressing and ongoing detention of the witnesses with a consequent violation of their right to liberty.

At a hearing in June 2011, Trial Chamber II evaluated the extent of the ICC's duty to protect detained witnesses from potential human rights violations. Its analysis dissected the 'risk' the witnesses faced on their return to the DRC into three types: the risk resulting from their testimony; the broader risk of human rights violations; and the general risk of persecution of ICC witnesses on return to their countries of origin, which might give rise to a valid asylum claim. ${ }^{36}$ The Chamber concluded that the ICC's obligations under Article 68 of the Rome Statute extended to the first risk type only, noting the provision's wording (only) required the ICC to 'take all protective measures necessary to prevent the risk witnesses incur on account of their cooperation with the Court'. ${ }^{37}$ This conclusion was based upon a contextual interpretation of Article 68, having regard to the range of protective measures governed by other provisions concerning protective measures, including Rule 87 of the RPE and Regulation 96 of the Regulations of the Registry. ${ }^{38}$ While the Chamber considered its obligations under Article 21(3) of the Rome Statute (i.e., to interpret and apply the law in accordance with internationally recognized human rights), it concluded that this did not expand the restrictive concept of 'risk' envisaged by Article $68 .^{39}$ Thus, in respect of the second category of risk, the Chamber held that the ICC has no remit to apply Article 68 to either protect witnesses from refoulement, or to prevent potential human rights violations more generally. We shall return to evaluate the Chamber's reasoning in this respect in the following section. Finally, with regard to the last type of risk, in agreeing the ICC cannot prejudice the ongoing asylum procedure before the Dutch authorities, the Chamber concluded that Article 21(3) does not impose an obligation on the ICC to ensure that state parties (in this case, the Netherlands) apply international human rights law to their domestic proceedings. ${ }^{40}$

Caught in a seemingly insoluble situation, the ICC sought a viable solution. ${ }^{41}$ It placed reliance upon diplomatic assurances received from the then DRC Minister of Justice and Human Rights, Bambi Lessa, that the witnesses would not be harmed upon return. ${ }^{42}$ Additionally, following consultations with both the VWU and DRC authorities, the ICC identified a suitable detention centre for the three, and secured an undertaking that the VWU would be notified in advance of any plan to transfer the witnesses to a different location. ${ }^{43}$ The ICC received additional assurance that as a result of protective measures, the witnesses would not be kept in permanent isolation; they would be assigned specially-trained guards, chosen jointly by the VWU and Congolese prison authorities; they would receive confidential visits twice a week from a VWU member; and when tried, an ICC observer would be authorized to attend the domestic proceedings. ${ }^{44}$ Eventually, in July 2014, the DRC Three were returned to the DRC authorities, having exhausted all attempts to gain asylum in the Netherlands.

\footnotetext{
${ }^{36}$ Ibid., at 59 .

${ }^{37}$ Ibid., at 61 (emphasis added).

${ }^{38}$ Ibid.

${ }^{39}$ Ibid., at 62 .

${ }^{40} \mathrm{Ibid}$.

${ }^{41}$ ICC, Prosecutor v. Germain Katanga And Mathieu Ngudjolo Chui, Decision on the security situation of three detained witnesses in relation to their testimony before the Court (art. 68 of the Statute) and Order to request cooperation from the Democratic Republic of the Congo to provide assistance in ensuring their protection in accordance with article 93(1)(j) of the Statute, ICC-01/04-01/07-3033, Trial Chamber II, 22 June 2011, at 40.

${ }^{42}$ Ibid.

${ }^{43}$ Ibid., at 41 .

${ }^{44}$ Ibid.
} 


\section{Examining the ICC's assessment of its human rights obligations to witnesses}

This section evaluates the Trial Chamber's assessment of its human rights obligations to witnesses, such as the DRC Three, and it will be argued that the ICC/IO is doubly-bound to protect witnesses from refoulement: firstly, by Article 21(3) of the Rome Statute (Section 2.1) and, secondly, according to international human rights law (Section 3.2). Each source is considered in turn.

\subsection{The ICC's obligations under the Rome Statute}

As we have seen already, Article 21(3) of the Rome Statute, relating to the applicable law, requires the ICC to interpret and apply the law enshrined in Article 21(1 $)^{45}$ in a manner consistent with internationally recognized human rights. ${ }^{46}$ Thus, when Article 68 mandates the ICC to take 'appropriate measures to protect [witnesses'] safety', this must be construed in light of Article 21(3). However, the obligation's clear extent contained in Article 21(3) is uncertain. ${ }^{47}$

The travaux préparatoires offer little legislative history on Article 21(3), as this article is a late addition to the Statute..$^{48}$ There are no provisions equivalent to Article 21(3) in the 1994 International Law Commission Draft Statute for an International Criminal Court. ${ }^{49}$ The 'Zutphen Draft' mentioned for the first time in a footnote that the interpretation and application of general sources of law must be consistent with 'international human rights standards'.$^{50}$ In the end, this provision was included in the final draft of the Statute without brackets or further clarification.

For this reason, Article 21(3) remains one of the most challenging interpretative provisions of the Rome Statute. The general academic consensus is that Article 21(3) constitutes a 'mandatory principle of consistency ${ }^{51}$ to ensure that all interpretations are consistent with human rights and 'overriding interpretive guidance, ${ }^{52}$ such that the ICC is not obliged to apply a specific legal provision that would clash with 'internationally recognized human rights'. In addition, others argue that Article 21(3) gives rise to an additional 'generative ${ }^{53}$ or 'gap-filling'54 power, which allows the ICC to go beyond the strict letter of the Rome Statute. According to this view, Article 21(3) operates as a 'multiple renvoi' to protect 'internationally recognized human rights' whenever

\footnotetext{
${ }^{45}$ Article 21(1) states: 'The Court shall apply: (a) In the first place, this Statute, Elements of Crimes and its Rules of Procedure and Evidence; (b) In the second place, where appropriate, applicable treaties and the principles and rules of international law, including the established principles of the international law of armed conflict; (c) Failing that, general principles of law derived by the Court from national laws of legal systems of the world including, as appropriate, the national laws of states that would normally exercise jurisdiction over the crime, provided that those principles are not inconsistent with this Statute and with international law and internationally recognized norms and standards.'

${ }^{46}$ Zeegers, supra note 21 , at 73 .

${ }^{47}$ On the relationship of Arts. 21(3) and 68 of the Rome Statute see Section 4.3.

${ }^{48}$ K.-S. Gallant, 'Individual-Human-Rights in a New International Organisation: The Statute of the International Criminal Court', in M. C. Bassiouni (ed.), International Criminal Law: Enforcement (1999), 489-703.

${ }^{49}$ ILC, 'Report of the International Law Commission on the work of its $46^{\text {th }}$ session, Official Records of the General Assembly', $49^{\text {th }}$ sess. Supp. No. 10, A/49/10 (1994).

${ }^{50}$ Draft Report of the Inter-Sessional Meeting from 19 to 30 January 1998 in Zutphen, The Netherlands, A/AC.249/1998/ L.13(1998) 63, fn 117.

${ }^{51}$ Zeegers, supra note 21; K. S. Gallant, 'Individual Human Rights in a New International Organisation: The Statute of the International Criminal Court', in Bassiouni, supra note 48, at 704; R. Young, “Internationally Recognised Human Rights” Before the International Criminal Court', (2011) 60 International Criminal Law Review 189, at 207.

${ }^{52}$ R. Young, supra note 51, at 202; L. Gradoni, 'The Human Rights Dimension of International Criminal Procedure', in G. Sluiter et al. (eds.), International Criminal Procedure: Principles and Rules (2013), 74, at 80-5, 93; D. Akande, 'Sources of International Criminal Law', in A. Cassese (ed.), The Oxford Companion to International Criminal Justice (2009), 41, at 47.

${ }^{53} \mathrm{D}$. Sheppard, "The International Criminal Court and "Internationally Recognized Human Rights": Understanding Article 21(3) of the Rome Statute', (2010) 10 International Criminal Law Review 43, at 57-63.

${ }^{54}$ Young, supra note 51, at 201.
} 
there is a lacuna in the Statute. ${ }^{55}$ This broader understanding of Article 21(3) finds support in ICC practice. For instance, in Lubanga, Trial Chamber I ordered the stay of the proceedings because a fair trial was no longer possible. ${ }^{56}$ In upholding Trial Chamber I's decision, the Appeals Chamber clarified that although this remedy was not available in the Rome Statute and in the RPE, this was based on Article 21(3). ${ }^{57}$ Also, following a content analysis of 395 judicial decisions in Lubanga, Jones concluded that there is a solid and widespread basis for this function of Article 21(3). ${ }^{58}$ This point is not further contested by scholars. ${ }^{59}$ Applying this principle to the ICC's obligation to detained witnesses under Article 68 first requires identification of an existing lacuna within the ICC legal framework in the sense of a type of risk - i.e., refoulement - which is not provided for elsewhere in the Statute. The second step is to demonstrate that protection from refoulement is an internationally recognized human right. ${ }^{60}$

Academics who agree that Trial Chamber II is right to focus solely on the risk arising from the witnesses' co-operation with the ICC, ${ }^{61}$ do not contest that non-refoulement is an internationally recognized human right (the second limb of the analysis). Rather, their argument that Article 21(3) should not expand the scope of witness protection under Article 68 is based upon concern that the ICC/Court is ill-equipped to assess any broader risks, and that requiring it to do so would create an undue burden on a court already struggling to protect witnesses. ${ }^{62}$ Another concern is that this approach would transform the ICC into an international human rights court that would intrude into states' domestic affairs. ${ }^{63}$

It is true that the ICC is not a human rights court, so concern surrounding its capability to assess a broad range of risks has some merit. However, the pertinent question for our purposes is to ask whether the ICC/Court (or only a human rights court) is able to assess the risks relevant to refoulement. Additionally, such concerns seem at odds with actions taken under the auspices of the ICC/IO in this case. For example, the Registry ${ }^{64}$ had secured assurances from the DRC authorities to provide advance notice of all future domestic legal proceedings that involved the detained witnesses $^{65}$ so an ICC observer could be present. ${ }^{66}$ It is implicit in this action that the Registry assessed risks beyond those linked to participation in ICC proceedings as per a narrow interpretation of Article 68. What would the observer's role be if not to verify that domestic proceedings were being conducted fairly? Moreover, the view that the ICC/Court is unable to assess more general risks does not hold given how the Registry has relied on diplomatic assurances when negotiating its co-operation with the DRC authorities. Whenever a deportation with assurances is agreed, it is preceded by a risk assessment to ensure the receiving state will comply with assurances

\footnotetext{
${ }^{55}$ Gradoni, supra note 52 , at 86.

${ }^{56}$ Prosecutor v. Lubanga, Decision on the Consequences of Non-Disclosure of Exculpatory Materials Covered by Article 54(3)(e) Agreements and the Application to Stay the Prosecution of the Accused, Together with Certain Other Issues Raised at the Status Conference on 10 June 2008, ICC-01/04-01/06-1401, Trial Chamber I, 13 June 2008 , para. 77.

${ }^{57}$ Prosecutor v. Lubanga, Judgment on the Appeal of the Prosecutor against the Decision of Trial Chamber I Entitled 'Decision on the Consequences of Non-Disclosure of Exculpatory Materials Covered by Article 54(3)e Agreements and the Application to Stay the Prosecution of the Accused, Together with Certain Other Issues Raised at the Status Conference on 10 June 2008, ICC-01/04-01/06-1486, Appeals Chamber, 21 October 2008, at 79-80.

${ }^{58} \mathrm{~A}$. Jones, 'Insights Into an Emerging Relationship: Use of Human Rights Jurisprudence at the International Criminal Court', (2016) 16(4) Human Rights Law Review 701.

${ }^{59}$ Irving, supra note 7 , at 16-20.

${ }^{60}$ See Section 3.2.2.

${ }^{61}$ E. Irving, 'The Relations between the International Criminal Court and its Host State: The Impact on Human Rights', (2014) 27 Leiden Journal of International Law 479, at 490; van Wijk and Cupido, supra note 9, at 1086-7.

${ }^{62}$ Irving, ibid.

${ }^{63}$ van Wijk and Cupido, supra note 9, at 1091.

${ }^{64}$ The Registry is a neutral organ of the ICC that provides administrative services to support the ICC's other organs: the Presidency, the Judicial Divisions, and the Office of the Prosecutor.

${ }^{65}$ ICC, Prosecutor v. Katanga and Ngudjolo Chui, Decision on the Security Situation of Witnesses DRC-D02-P0236, DRC-D02-P-0228 et DRC-02-P-0350, ICC-01/04-01/07-3128, Trial Chamber II, 24 August 2011, at 6.

${ }^{66}$ Ibid.
} 
given and respect its duty to prevent a human rights violation. ${ }^{67}$ Presumably, in our case of the DRC Three, the Registry only agreed to return the witnesses to the DRC having first ensured the Congolese authorities were likely to comply with the agreed terms.

Therefore, the Registry has, in practice, entered into a deportation agreement with the DRC authorities, although the Trial Chamber II had previously ruled that Article 21(3) could not be used to expand the scope of Article 68. These actions undermine the stance that the ICC is only bound to protect witnesses to a limited extent, i.e., in respect of risk arising solely from their co-operation with the court. The ICC's actions endorse the viewpoint that Article 21(3) provides a wider mandate ${ }^{68}$ which should broadly protect witnesses against human rights violations. With this conclusion, the next part considers whether the ICC enjoys any additional competency stemming from international human rights law.

\subsection{The ICC's obligations under international human rights law}

Following submissions made in Germain Katanga's defence, Trial Chamber II was required to consider whether the ICC should protect witnesses based upon the customary rule of non-refoulement. ${ }^{69}$ It concluded:

[A]s an international organisation with a legal personality, the Court cannot disregard the customary rule of non-refoulement. However, since it does not possess any territory, it is unable to implement the principle within its ordinary meaning, and hence is unlikely to maintain long-term jurisdiction over persons who are at risk of persecution or torture if they return to their country of origin. In the Chamber's view, only a State which possesses territory is actually able to apply the non-refoulement rule. ${ }^{70}$

While the Chamber's analysis is correct in respect of the first two points, it drew the wrong conclusion: the ICC is bound by customary law as an international organization, and non-refoulement is customary law. However, it does not follow this because the ICC is not a state (and lacks territory), so it cannot apply the principle of non-refoulement. A more careful analysis of this aspect is needed. Indeed, as will now be explained, there is no justification - either under international law regulating the obligations of international organizations, or under customary law concerning the principle of non-refoulement - for narrowing the ICC's responsibility in terms of witness protection.

\subsubsection{The ICC and customary law}

It is uncontentious that the ICC is an international organization, even though an exact definition of 'international organization' does not exist in international law. ${ }^{71}$ Public international organizations share certain key characteristics that identify them. ${ }^{72}$ First, they are established by an international treaty or convention by member states. In this regard, the ICC was established by the Rome Statute in 1998. This is a multilateral international law instrument with 124 member states. Secondly, it must possess international legal personality, namely, the ability to accept rights and obligations under international law. ${ }^{73}$ In the case of the ICC, Article 4 of the Rome Statute clearly

\footnotetext{
${ }^{67}$ Giuffré, supra note 16 , at $79-82$.

${ }^{68} \mathrm{D}$. Sheppard, 'The International Criminal Court and "Internationally Recognized Human Rights": Understanding Article 21(3) of the Rome Statute', (2010) 10 International Criminal Law Review 43, at 57-63; Young, supra note 51, at 201; Gradoni, supra note 52, at 86.

${ }^{69}$ Decision on an Amicus Curiae, supra note 3, at 64.

${ }^{70}$ Ibid.

${ }^{71}$ N. D. White, The Law of International Organisations (2005), at 1.

${ }^{72}$ C. F. Amerasinghe, Principles of the Institutional Law and International Organisations (2005), 9; White, ibid., at 1.

${ }^{73}$ Reparations for Injuries Suffered in the Service of the United Nations (UN v. France and UK), Advisory Opinion, Judgment of 11 April 1949, [1949] ICJ Rep. 174, at 180.
} 
states that ' $[\mathrm{t}]$ he Court shall have international legal personality'. ${ }^{74}$ Furthermore, in September 2020, the Independent Expert Review of the International Criminal Court and the Rome Statute System has further confirmed the dual nature of the ICC as both a judicial entity (ICC/Court) and an international organization (ICC/IO). ${ }^{75}$ The Report clarifies that this distinction corresponds to a three-layered model of governance of the ICC: judicial and prosecutorial activity (layer 1), administration of justice (layer 2), and administration of the international organization (layer 3). ${ }^{76}$ The former two layers are entrusted to the Presidency and the Office of the Prosecutor while the latter to the Registrar. ${ }^{77}$ This is why Trial Chamber II gave the mandate to the Registry to liaise with the DRC authorities. ${ }^{78}$

The immediate consequence of this feature is that the source of law establishing a human rights obligation determines the obligations for the ICC/IO. The ICJ ruled in the Advisory Opinion on Interpretation of the Agreement of 25 March 1951 between the World Health Organization and Egypt (hereinafter, WHO-Egypt Advisory Opinion) that international organizations 'are subjects of international law and, as such, are bound by any obligation incumbent upon them under general rules of international law' ${ }^{79}$ Although the ICJ did not specify what 'general rules of international law' comprise, there is scholarly consensus that this category encompasses customary international law. ${ }^{80}$

Although some scholars merely assert that international organizations should respect customary law, ${ }^{81}$ two main theories are used to justify why international organizations should be bound by customary law. ${ }^{82}$ The first theory is that the obligation is founded in the international organizations' legal personality. ${ }^{83}$ Just as states with international legal personality are subjected to international customary law, so should international organizations with international legal personality be equally bound. Others have already relied upon this theory to extend, by analogy, states' obligations under customary law to international organizations with international personality. ${ }^{84}$ Why should a new state automatically comply with customary law (even absent explicit consent) if established international organizations need not? ${ }^{85}$ The second theory relies upon the fact that by signing an international treaty, a signatory state transfers certain of its legal obligations to the international organization. A state cannot transfer more power than it holds. ${ }^{86}$ It would

\footnotetext{
${ }^{74}$ Zeegers, supra note 21 , at 11.

${ }^{75}$ Independent Expert Review, supra note 20, at 12.

${ }^{76}$ Ibid., at 13 .

${ }^{77}$ Ibid.

${ }^{78}$ See Section 2.

${ }^{79}$ Interpretation of the Agreement of 25 March 1951 between the World Health Organisation and Egypt (WHO v. Egypt) Advisory Opinion, Judgment of 20 December 1980, [1980] ICJ Rep. 73, para. 27.

${ }^{80} \mathrm{~K}$. Daugirdas, 'How and Why International Law Binds International Organisations', (2016) 57 Harvard International Law 325; J. Pauwelyn, Conflict of Norms in Public International Law (2003), 148-9, 155-7; A. Zahar and G. Sluiter, International Criminal Law (2008), 277.

${ }^{81}$ H. G. Schermers and N. M. Blokker, International Institutional Law: Unity within Diversity (2011), 988; T. Meron, Human Rights and Humanitarian Norms as Customary Law (1989) 94-96; J. Wouters and C. Ryngaert, 'Impact on the Process of the Formation of Customary International Law', in M. M. T. Kamminga and M. Scheinin (eds.), The Impact of Human Rights Law on General International Law (2008), at 111-31; J. Wouters et al., 'Accountability for Human Rights Violations by International Organisations: Introductory Remark', in J. Wouters et al. (eds.), Accountability for Human Rights Violations by International Organisations: International Law (2010), 57; A. Clapham, 'Non-State Actors', in Moeckli et al. (eds.), International Human Rights Law (2014), 557, at 567; A. Ciampi, 'State Cooperation with the ICC and Human Rights', in M. Politi and F. Gioia (eds.), The International Criminal Court and National Jurisdictions (2009), 103 , at 103 .

${ }^{82}$ Zeegers, supra note 21 , at $12-25$.

${ }^{83}$ A. Reinisch, 'The Changing International Legal Framework for Dealing with Non-State Actors', in P. Alston (ed.), Non-State Actors and Human Rights (2005), 37, at 46; K. Wellens, Remedies Against International Organisations (2002), 15.

${ }^{84}$ Amerasinghe, supra note 72 , at 400 .

${ }^{85}$ Gradoni, supra note 52 , at 81 .

${ }^{86}$ Zeegers, supra note 21 , at 14 .
} 
seem illegitimate that states could establish an international organization to bypass an obligation otherwise imposed by international customary law. ${ }^{87}$

It is notable that certain decisions of the International Criminal Tribunals and Courts have discussed to what extent they consider themselves bound to respect customary human rights law. For instance, in Simić, the ICTY ${ }^{88}$ - in deciding that it did have the power to compel a witness employed by the International Committee of the Red Cross (ICRC) - stated: 'It is trite that the International Tribunal is bound by customary international law. ${ }^{\prime 9}$ Thus, it is clear the ICTY agreed to be bound by those rights recognized in customary law. There is additional case law consistent with this viewpoint. In Blaškić, the ICTY had to decide whether it could direct a binding order to a state official, rather than to the state itself. Here, the Appeals Chamber concluded that a state official's actions must be attributed to the state on the basis of the well-established rule of customary law, which prescribes 'functional immunity' for state officials. ${ }^{90}$ In finding so, the Chamber described customary law having 'always been respected, by international organizations as well as international courts'. ${ }^{91}$ Similarly, in Barayagwiza, the Appeals Chamber described the ICTR as 'a unique institution, governed by its own Statute and by the provisions of customary international law, where these can be discerned'. ${ }^{92}$

Therefore, it follows that if non-refoulement is established as customary human rights law, the ICC is bound by it.

\subsubsection{Non-refoulement as customary law}

The principle of non-refoulement is contained in Article 33 of the Refugee Convention and accepted as customary human rights law by Trial Chamber II. ${ }^{93}$ This view is also widely accepted among scholars. ${ }^{94}$ Subjective acknowledgement can be inferred from the UN General Assembly's frequent reference to the principle. ${ }^{95}$ For example, in Resolution 37/95 of 18 December 1982, the General Assembly reaffirmed that states should fully co-operate 'by acceding to and implementing the relevant international and regional refugee instruments and by scrupulously observing the principles of asylum and non-refoulement'. ${ }^{96}$ Additionally, the numerous instances in which states have responded to the UNHCR's representations by providing justifications on refoulement cases $^{97}$ constitutes an implicit confirmation of their acceptance of the basic principle.

\footnotetext{
${ }^{87}$ I. Brownlie, 'State Responsibility: the problem of delegation', in K. Ginther et al. (eds.), Völkerrecht zwischen normativen Anspruch und politischer Realität (1994), 300-1.

${ }^{88} \mathrm{ICTY}$, Prosecutor v. Simić et al., Decision on the Prosecution Motion under Rule 73 for a Ruling concerning the Testimony of a Witness, IT-95-9-PT, Trial Chamber II, 27 July 1999.

${ }^{89}$ Ibid., at 42 .

${ }^{90}$ ICTY, Prosecutor v. Blaškić, Judgement on the Request of the Republic of Croatia for Review of The Decision of Trial Chamber II of 18 July 1997, IT-95-14, Appeals Chamber, 29 October 1997, at 38-41.

${ }^{91}$ Ibid.

${ }^{92}$ ICTR, Prosecutor v. Barayagwiza, Decision, Prosecutor's Request for Review or Reconsideration, ICTR-97-19-Ar72, Appeals Chamber, 31 March 2000, at 69.

${ }^{93}$ Section 3.2 .

${ }^{94}$ Sir E. Lauterpacht and D. Bethlehem, 'The Scope and Content of the Principle of Non-Refoulement: Opinion', in E. Feller et al. (eds.), Refugee Protection in International Law: UNHCR's Global Consultations on International Protection (2013), 87.

${ }^{95}$ Among others see GA Res. 44/137 (15 December 1989); GA Res. 38/121 (16 December 1983); GA Res. 39/140 (14 December 1984); GA Res. 40/118 (13 December 1985); GA Res. 41/124 (4 December 1986); GA Res. 42/109 (7 December 1987); GA Res. 43/117 (8 December 1988); GA Res. 45/140 (14 December 1990); GA Res. 46/106 (16 December 1991); GA Res. 47/105 (16 December 1992).

${ }^{96}$ General Assembly, Report of the United Nations High Commissioner for Refugees, UN Doc. A/RES/37/195, (18 December 1982), at 2.

${ }^{97}$ United Nation High Commissioner for Refugees, Advisory Opinion on the Extraterritorial Application of Non-Refoulement Obligations under the 1951 Convention relating to the Status of Refugees and its 1967 Protocol (26 January 2007), at 15 .
} 
The objective element of customary law is demonstrated by the encompassment of nonrefoulement in binding and non-binding international instruments, including Article 3(1) of the Convention against Torture and Other Cruel, Inhuman or Degrading Treatment or Punishment; ${ }^{98}$ Article 2(3) of the Organisation of African Unity Convention of 10 September 1969 (governing specific aspects of refugee problems in Africa); ${ }^{99} 1966$ Principles Concerning Treatment of Refugees, adopted by the Asian African Legal Consultative Committee; ${ }^{100}$ the 1967 Declaration on Territorial Asylum adopted unanimously by the United Nations General Assembly (UNGA) as Resolution 2132 (XXII), 14 December 1967; ${ }^{101}$ the 1984 Cartagena Declaration; ${ }^{102}$ Article 22(8) of the IACHR; Article 3(2) of the 1957 European Convention on Extradition; ${ }^{103}$ and Article 4(5) of the 1981 Inter-American Convention on Extradition. ${ }^{104}$

In addition, the principle itself flows implicitly from the obligation to respect, protect, and fulfil certain human rights, such as the right to life, freedom from inhuman and degrading treatment, and right to fair trial. This obligation is clear in many cases concerning the extradition of convicted or alleged criminals to countries with the death penalty. One example is found in Chitat $\mathrm{Ng}$ v. Canada. Here, the Human Rights Council (HRC) determined that a Canadian decision to extradite an individual to the USA amounted to a violation of his right to be free from torture and inhuman and degrading treatment, ${ }^{105}$ since the possibility of the death penalty (execution by gas asphyxiation) constituted a violation. ${ }^{106}$ At the European level, the obligation of non-refoulement was established in the landmark extradition case of Soering. ${ }^{107}$ An extradition treaty imposed a legal obligation on the UK to transfer Soering, a German national, to the USA, where he could face capital punishment as a result of murder charges in the Commonwealth of Virginia. The European Court of Human Rights (ECtHR) upheld Soering's extradition challenge since extradition to the USA would expose him to a real risk of treatment which exceeded the prohibited threshold of torture. ${ }^{108}$

Subsequent case law of the ECtHR has extended the scope of non-refoulement to protect individuals from flagrant denial of liberty and justice. In Othman (Abu Qatada) v. United Kingdom, the applicant was a Jordanian national with refugee status in the UK, and faced deportation having been detained under the UK's Anti-terrorism, Crime and Security Act (2001). ${ }^{109}$ The ECtHR upheld the applicant's claim that deportation would violate non-refoulement. During his detention, he was convicted in absentia in Jordan based upon testimony evidence which had been obtained under torture. ${ }^{110}$ In 2013, Trial Chamber II itself extended this further. Having reviewed scholarship in this field ${ }^{111}$ and the General Conclusion on International Protection No. 25 produced by the Executive Committee of the High Commissioner's Programme that

\footnotetext{
${ }^{98}$ Adopted and opened for signature, ratification and accession by General Assembly resolution 39/46 of 10 December 1984 entry into force 26 June 1987.

${ }^{99} 1001$ UNTS 45.

${ }^{100}$ Asian-African Legal Consultative Committee, Report of the Eighth Session of the Asian-African Legal Consultative Committee, Bangkok, 8-17 Aug. 1966, 335.

${ }^{101}$ UN General Assembly, Declaration on Territorial Asylum, UN Doc. A/RES/2312(XXII), 14 December 1967.

${ }^{102}$ Cartagena Declaration on Refugees, embodying the Conclusions of the Colloquium on the International Protection of Refugees in Central America, Mexico, and Panama held in Cartagena, 19-22 November 1984.

${ }^{103}$ European Treaty Series No. 24.

${ }^{104}$ OAS Treaty Series No. 60, 45.

${ }^{105}$ HRC, Chitat Ng v. Canada, Communication No 469/1991, UN Doc. CCPR/C/49/D/469/1991 (1994).

${ }^{106}$ Ibid., para. 16.4. See also HRC, Roger Judge v. Canada, Communication No 829/1998, UN Doc. CCPR/C/78/D/829/1998 (20 October 2003).

${ }^{107}$ Soering v. United Kingdom, Decision of 7 July 1989, [1989] ECHR 439.

${ }^{108}$ Ibid. See also Al-Saadoon and Mufdhi v. United Kingdom, Decision of 30 June 2009, [2009] ECHR.

${ }^{109}$ Omar Othman (Abu Qatada) v. The United Kingdom, Decision of 9 May 2012, [2012] ECHR 1.

${ }^{110}$ Ibid.

${ }^{111}$ J. Allain, 'The Jus Cogens nature of non-refoulement', (2002) 13(4) International Journal of Refugee Law 533.
} 
acknowledged the principle was gaining traction as a peremptory rule of international law, ${ }^{112}$ it classified the principle of non-refoulement as jus cogens. ${ }^{113}$

The analysis is unaffected by the classification of non-refoulement as either customary law or jus cogens, since the ICC/IO is bound by both. However, as we have seen already, ${ }^{114}$ the ICC reasoned that it is unable to apply the principle of non-refoulement because, unlike a state actor, it lacks the territory needed to establish long-term jurisdiction over the detained witnesses.

However, it is apparent that the premises of Chamber's conclusion are dubious under two perspectives. First, non-refoulement, based upon its usual meaning, is an obligation of means owed to an individual 'not to return' them. ${ }^{115}$ It would be incorrect to interpret it as an obligation that entitles an individual to remain within a territory, which is more akin to the right to seek asylum. The reason why the Trial Chamber wrongly concluded that only duty-holders with a territory can implement the principle of non-refoulement is because it did not distinguish between the obligation to not return asylum seekers and their right to remain within a territory. While asylum requires a territory in which the individual may stay, the principle of non-refoulement may be upheld by not 'sending them back'.

Against this background, it is difficult to assess the extent to which the ICC/IO is bound to respect non-refoulement in a context where the ICC cannot keep those individuals within its territory. ${ }^{116}$ With this background in mind, the final part in this section focuses on the second controversial aspect. It aims to ascertain whether the lack of territory per se is a valid legal basis to restrict the ICC/IO's responsibility to protect those witnesses or whether the ICC should play any role in finding a place where those witnesses might reside.

\subsubsection{The ICC and non-refoulement}

The human rights obligations of international organizations are generally operationalized 'through the prism of due diligence'. ${ }^{117}$ Due diligence is an obligation of conduct according to which the duty holder must 'deploy adequate means, to exercise best possible efforts, to do the utmost, to obtain this result'. ${ }^{118}$ Whereas a state possesses the totality of international rights and duties and would have had the chance to deal with the situation of undesirable and unreturnable witnesses within its territory, the extent of due diligence for the ICC/IO 'depend[s] upon its purposes and functions as specified or implied in its constituent documents and developed in practice'. ${ }^{119}$ Thus, the ICC's due diligence must be assessed against this framework.

The ICC was established to fight the most heinous human rights violations committed with impunity. It would be counterintuitive to argue that it is not obliged to follow the very obligations which it respects, not least because the Rome Statute makes reference throughout to human rights law. Human rights law is also intertwined with how norms are interpreted and applied according to Article 21(3) of the Rome Statute. In addition to these elements, we must be mindful of the consequences of affirming that such organizations have any weaker obligation to respect human

\footnotetext{
${ }^{112}$ General Assembly, General Conclusion on International Protection No 25 (XXXIII) - 1982, UN Doc. A/37/12/Add.1, 20 October 1982.

${ }^{113}$ ICC, Prosecutor v. German Katanga, Decision on the application for the interim release of detained Witnesses DRCD02-P-0236, DRC-D02-P-0228 and DRC-D02-P-0350, ICC-01/04-01/07-3405-tENG, Trial Chamber II, 11 November 2013, at 30 ('Interim Release').

${ }^{114}$ Section 3.2.

${ }^{115}$ Velásquez-Rodriguez v. Honduras, Decision of 29 July 1988, IACtHR Series C No 4, para. 172. See also N. S. Rodley, 'Integrity of the Person', in Moeckli et al. (eds.), International Human Rights Law (2014), 165, at 174.

${ }^{116}$ A. Clapham, Human Rights Obligations of Non-State Actors (2006), at 563.

${ }^{117}$ Ibid., at 151.

${ }^{118}$ International Tribunal for the Law of the Sea, Responsibilities and Obligations of States Sponsoring Persons and Entities with Respect to Activities in the Area, Case No. 17, Advisory Opinion of 1 February 2011, 15 ITLOS Report 10, at 110.

${ }^{119}$ Advisory Opinion of the International Court of Justice Concerning Reparation for Injuries Suffered in the Service of the United Nations, Judgment of 11 April 1949, [1949] ICJ Rep. 174.
} 
rights than the states that create them. Otherwise, we might expect states unwilling to abide by certain customary law obligations to create international organizations to avoid them. ${ }^{120}$ However, as clarified by Cassese, as any international criminal court or tribunal, the ICC is like a giant without arms and legs [which] needs artificial limbs to walk and work'. ${ }^{121}$ Thus, the Rome Statute requires states parties to co-operate with the ICC in matters concerning the enforcement of arrest warrants, surrender of persons, conduct of investigations on states' territory, witness protection, and serving of sentences. ${ }^{122}$

Thus, in questioning whether the ICC/IO has acted with due diligence by taking all reasonable steps to protect witnesses from non-refoulement and any violation they might experience because of their involvement with the ICC, the lack of a territory might present an obstacle to the ICC's implementation of certain human rights. However, it is appropriate to review how the ICC has overcome the same issue in other circumstances. Here, it is relevant that the ICC concluded ad hoc agreements with 18 state parties so that it may (lacking a territory of its own) relocate protected witnesses in one of these states. ${ }^{123}$ Additionally, in the case of a convicted prisoner, Article 103(1)(a) of the Rome Statute permits the ICC to designate a state from a list of willing states for the individual to serve their sentence. Against this backdrop, Trial Chamber II sought to distinguish the circumstances of the DRC witnesses from previous examples by arguing that it 'cannot employ the cooperation mechanisms provided for by the Statute in order to compel a state party to receive onto its territory an individual invoking this [non-refoulement] rule'. ${ }^{124}$ Thus, while the ICC has an obligation to protect witnesses from refoulement by employing all reasonable steps to prevent witnesses from being returned home, it is also true the ICC cannot compel another state to accept witnesses (including those who are prisoners). Thus, it makes the ICC dependent on political interests of states. Given the lack of clear guidance on how this responsibility may be discharged in practice, the next sessions will canvass some possible solutions.

\section{Canvassing possible solutions}

How should the ICC protect those witnesses by upholding the principle of non-refoulement? In the case of the DRC Three, the ICC followed the tried and tested route of 'diplomatic assurances', used to facilitate the transfer of individuals who are 'unreturnable' but 'undesirable' because they are either suspected or convicted of a serious crime. ${ }^{125}$ However, this option is quite onerous in terms of time, cost, and personnel and might not always be a viable solution in the circumstances. Thus, either the ICC chooses some witnesses with a less sticky situation or, if the testimony of detained witnesses is deemed necessary, this section evaluates a range of suggested options available to the ICC, should similar circumstances present themselves again.

\subsection{The 'van Wijk and Cupido' solution}

Some authors attempt to avoid the issue altogether. Rather than transferring a witness to The Hague, they propose moving the ICC proceedings to the witness's state of residence so they can give testimony while in jail via video-link. ${ }^{126}$ While keeping a witness in their country of origin, rather than transferring them to The Hague (where the ICC would detain them and where they could apply for asylum) might be technically compliant with human rights law, this option is

\footnotetext{
${ }^{120}$ See Section 3.2.1.

${ }^{121}$ Cassese, supra note 26.

${ }^{122}$ Arts. 87 and $89(1)$ of the Rome Statute.

${ }^{123}$ ICC website, www.icc-cpi.int/about/witnesses (accessed 17 April 2020).

${ }^{124}$ Decision on an Amicus Curiae, supra note 3, at 64.

${ }^{125}$ Giuffré, supra note 16 , at 77 .

${ }^{126}$ van Wijk and Cupido, supra note 9, at 1084.
} 
not without drawbacks. Indeed, the authors also admit to an unsolved 'moral quandary': ${ }^{127}$ what if a detained witness were to insist on testifying in person at The Hague? Would it be open to the ICC to refuse such a request if, for example, the ICC would suspect this request was for the witness to lodge an asylum application? Also, this solution fails to address security issues a witness may face once they agreed to testify before the ICC. Finally, it speaks volumes of the ICC's (in)ability to defend witnesses and their rights.

Alternatively, and particularly if there are concerns about the witness's safety in situ, some authors recommend the witness could be taken to a neutral venue or third country to give evidence before a rogatory commission. ${ }^{128}$ Whereas this solution would avoid moving detained witnesses to The Hague, it does not solve the issues at stake. First, it might encounter resistance from countries asked to co-operate with the ICC in receiving detained witnesses within their detention facilities. Second, it might pose the same legal, political, and practical challenges of the suggestion to move witnesses to The Hague considering that those individuals might apply for asylum in the third country. ${ }^{129}$ In this case, the role of the ICC would become more delicate because the third state would likely retain power to analyse the issues of non-refoulement and asylum applications and to send those witnesses (that are de facto within its jurisdiction) back to their country of origin. ${ }^{130}$ Once again, this solution would reveal the ICC's weaknesses in protecting witnesses' rights.

Finally, under both circumstances, isolating witnesses from the main trial may have a negative impact on the proceedings. It may undermine the defendant's right to cross-examine those giving evidence which implicates them and undermines the ICC's ability to test the credibility of a witness and the reliability of their testimony. Overall, based upon the shortcomings identified, this solution is not recommended to the ICC.

\subsection{Strengthen co-operation with the ICC's host state}

The ICC is headquartered in The Hague. Another existing proposal suggests that the ICC could rely upon a detention unit already located within the Netherlands as the ICC's host state. ${ }^{131}$ This proposal has the advantage that it enjoys a strong legal basis because it is possible to apply, by analogy, a provision in the Rome Statute concerning the imprisonment of successfully prosecuted defendants. Article 103(4) states: 'If no State is designated ... the sentence of imprisonment shall be served in a prison facility made available by the Host State.' This option is a seemingly simple solution to the ICC's lack of territory which enables a detained witness to serve their remaining sentence. Equally, the existing rule's extension is easily justified, since the same legal gap exists in relation to individuals seeking asylum in the Netherlands in both situations (non-refoulement and imprisonment).

According to its proponents, Article 103(4) triggers residual, subsidiary, and collateral responsibility of the host state to the ICC based upon the establishment of The Hague as a juridical enclave' within the territorial jurisdiction of the Netherlands. ${ }^{132}$ Even though ICC premises are inviolable and subject to the ICC's sole control and authority, the host state's laws and regulations apply on ICC premises unless otherwise provided in the agreement between the ICC and host state. ${ }^{133}$

\footnotetext{
${ }^{127}$ Ibid.

${ }^{128}$ Ibid., at $1101-3$.

${ }^{129}$ See Section 4.3 .

${ }^{130}$ On this point, please see Section 4.3 .

${ }^{131}$ G. A. M. Strijards, 'Article 103', in O. Triffterer (ed.), Commentary on the Rome Statute of the ICC: Observers Notes, Article by Article (2008), at 1656-7. Sluiter, supra note 6, at 667.

${ }^{132}$ Strijards, ibid.

${ }^{133}$ Headquarters Agreement between the International Criminal Court and the Host State, ICC-The Netherlands, signed 7 June 2007, ICC-BD/04-01-08 (Date of entry into force 1 March 2008), Arts. 6 and 8.
} 
Despite its merits, certain difficulties remain. First, this solution does not address the political dimension of this request. The Netherlands may unwillingly be the only country to receive all the witnesses the ICC approaches (and will approach in future). Second, this solution would leave the witnesses' fate in the hands of the Dutch authorities to decide on the issue as a purely internal matter without considering the involvement of those witnesses with the ICC. ${ }^{134}$ Research shows the Dutch approach is quite strict, as undesirable and unreturnable aliens are excluded from all residence permits even if it clashes with EU law. ${ }^{135}$ In 2014 the Netherland established the so-called 'crimmigration prisons', which exclude foreign national prisoners from rehabilitation programmes because they are expected to be deported at the end of their sentence. ${ }^{136}$

Against this background, it is clear that the ICC cannot pass its responsibility to protect witnesses to the host state, especially considering it is an onerous burden for only one country. In light of these shortcomings, the next section considers whether there is a greater role to be played by protective measures.

\subsection{Strengthening the role of protective measures}

Article 68 of the Rome Statute requires the ICC to take 'appropriate measures to protect the safety, physical and psychological well-being, dignity and privacy' of a witness who participates in ICC proceedings. Typical measures include: expunging from public records the name of any victim, witness, or other person at risk on account of testimony given during proceedings; prohibiting disclosure of sensitive information to third parties; permitting testimony to be given with audio only, or using electronic means to disguise witness identity; using audio-visual technology, such as video-conferencing or closed-circuit television; using pseudonyms; and/or conducting the proceedings in camera. ${ }^{137}$ In addition, the ICC may not only invoke 'any combination' of the protective measures listed above, but also 'any modification of a measure ordered by the Chamber which is technically feasible'. ${ }^{138}$ In the case of the DRC Three, Trial Chamber II concluded it was unable to invoke special protective measures generally designed to facilitate the testimony of a traumatized victim or witness, a child, an elderly person, or a victim of sexual violence because these serve specific roles different to the prerequisites of non-refoulement. ${ }^{139}$

It is true that Article 68 is intended to protect witnesses from risks associated with their testimony and general co-operation with the ICC, whereas non-refoulement safeguards individuals from broader risks concerning their fundaments rights, which might be violated by, for example, inhuman and degrading treatment or by flagrant denial of justice. However, as argued above, the Chamber's narrow interpretation of 'appropriate measures' is not entirely convincing. ${ }^{140}$ Indeed, a contextual interpretation of Article 68, consistent with 'internationally recognized human rights' under Article 21(3) of the Rome Statute and the due diligence principle, demonstrates a broader understanding of 'appropriate measures' could be pursued not least because the ICC's Registry proved it is equipped to assess a broader range of risks. ${ }^{141}$ This approach also answers the more

\footnotetext{
${ }^{134}$ van Wijk, supra note 6, at 191.

${ }^{135}$ M. P. Bolhuis, H. Battjes and J. van Wijk, 'Undesirable but Unreturnable Migrants in the Netherlands', (2017) 36, Refugee Survey Quarterly 1, at 84. See also Reijven and Van Wijk, supra note 4.

${ }^{136} \mathrm{~J}$. Brouwer, 'Bordered penality in the Netherlands: The experiences of foreign national prisoners and prison officers in a crimmigration prison', (2020) 22 Punishment \& Society 5, at 703.

${ }^{137}$ Rule 87, Rules of Procedure and Evidence of the International Criminal Court, ICC-ASP/1/3, at 10, and Corr. 1 (2002), UN Doc. PCNICC/2000/1/Add.1 (2000).

${ }^{138}$ Regulation 94 of the Regulation of the Registry, ICC-BD/03-03-13.

${ }^{139}$ See Section 3.1 .

${ }^{140}$ Ibid.

${ }^{141}$ Ibid.
} 
sceptical voices that argue Article 21(3) cannot generate powers or remedies that have no legal basis in the Rome Statute framework. ${ }^{142}$

Accordingly, it is proposed here that the ICC should rely on its existing ICC Protection Programme (ICCPP). This relocates witnesses, on a temporary or permanent basis, ${ }^{143}$ via an arrangement of ad hoc agreements between the ICC and willing states to guarantee long-term protection where there are practical difficulties owing to the ICC's lack of territory. It is logical to apply the same solution to overcome the same territorial barrier to obligations of non-refoulement that Trial Chamber II found insurmountable. ${ }^{144}$ This solution would allow the ICC not only to rely on the Netherlands, as suggested by Irving, ${ }^{145}$ but since the ICC already has 18 agreements in place, it is proposed the ICC should endeavour to seek revision of the ad hoc agreements already in place to specifically encompass its obligation of non-refoulement. In this way, a witness with a genuine fear for their life and security would not need to seek asylum because they will receive protection from refoulement in a willing state.

The viability of this solution can be questioned under several perspectives. First, it is not clear which rights those individuals will enjoy. For instance, Irving seems to suggest that a relocated witness might enjoy fewer procedural and substantial rights than would be provided under refugee law. ${ }^{146}$ However, such concerns seem allayed by the clarification provided by the Dutch District Court, that the level of protection offered under the ICCPP is equivalent to the human rights protection afforded by the ECtHR. ${ }^{147}$ Additionally, the ICC has subsequently explained that ' $[t]$ he only minimum requirement' under the ICCPP 'is that permanently relocated witnesses receive facilities, benefits, and entitlements, which should be at least equal to that which is provided to refugees under Article 1 of the Convention and its Protocol relating to the Status of Refugees'. ${ }^{148}$ Thus, a protected witness would not appear to be disadvantaged, in this regard, in comparison with a refugee.

Second, the lack of enforcement system could undermine the functioning of the ICC's obligation to co-operate with member states. ${ }^{149}$ Indeed, some states might find it undesirable to co-operate for the benefit of relocated, detained, infiltrated, or insider witnesses. A special issue of the Refugee Survey Quarterly analysed challenges that undesirable and unreturnable aliens pose to the asylum and immigration domestic framework. ${ }^{150}$ Eight case studies (Australia, Canada, France, Greece, India, the Netherlands, Turkey, and the United Kingdom) contained examples of undesirable and unreturnable aliens who requested entry into third countries without success because of serious reasons to consider they committed crimes under Article 1(f) of the Refugee Convention. ${ }^{151}$ In addition, it helped clarify that the international framework on this point is fragmented because each state produced a different response and none had long-term solutions.

Using a narrower focus, there are several reasons why the ICC might encounter some resistance. Domestic legislations might not have measures to absorb individuals who represent

\footnotetext{
${ }^{142}$ Irving, supra note 7 , at 18.

${ }^{143}$ Regulation 96, Regulation of the Registry.

${ }^{144}$ See Section 3.2.

${ }^{145}$ Irving, supra note 7 , at 201.

${ }^{146}$ Irving (2014) supra note 19, at 1146. Irving, supra note 7, at 204.

${ }^{147}$ Rechtbank Amsterdam, 14 October 2013 (ECLI 6688), paras 10.6.4, 10.74 (ECLI 6692) and para 9.3.6 an 9.4.5 (ECLI 6705).

${ }^{148}$ ICC, Cooperation Agreement, at 10, available at www.icc-cpi.int/news/seminarBooks/Cooperation_Agreements_Eng. pdf?fbclid=IwAR3WgNJ-FJaRWpTRvQugEWjK0gAEJIajBoknOZkatBbrxDt5ralhUAupuH0 (accessed 17 April 2020).

${ }^{149} \mathrm{G}$. Sluiter, 'The surrender of war criminals to the International Criminal Court', (2002-2003) 25 Loyola Los Angeles International and Comparative Law Review 605, at 606; Cassese, supra note 26, at 13; C. Kress and K. Prost, 'Surrender of persons to the Court', in O. Triffterer (ed.), Commentary of the Rome Statute of the International Criminal Court. Observers' Notes, Article by Article (2008), at 615.

${ }^{150}$ Cantor et al., supra note 18 , at $1-8$.

${ }^{151}$ Ibid.
} 
a danger to their society and/or to prosecute detained witnesses under this scheme. ${ }^{152}$ Even then, if states accept a detained witness, it is necessary to recognize limits and challenges faced in an extraterritorial criminal prosecution of an unreturnable individual, such as difficulties securing evidence and other calls upon limited domestic resources. Finally, they might be caught in a 'legal limbo', as they might end up in the ranks of non-removed rejected asylum seekers, who are assumed to unofficially reside in the host country but cannot be removed due to legal and practical constraints. ${ }^{153}$ This situation might create further challenges given that European states are obliged to provide a minimum level of social benefit according to the Return Directive 2008/115/EU. ${ }^{154}$

Domestic immigration policies in this field expose the limits of state authority when dealing with undesirable and unreturnable witnesses and the lack of harmonization with international criminal law. ${ }^{155}$ However, the situation described in this article is different because these witnesses are undesirable and unreturnable because of their involvement with the ICC. The Rome Statute framework offers a solution. Article 87(7) of the Rome Statute establishes that where a state party fails to comply with a co-operation request from the Court, the ICC may refer the matter to the ASP. The aim of this provision is to bring the matter to a plenary body to examine and publicize the problem. ${ }^{156}$ Although there is some room to discuss whether stronger political and diplomatic measures are necessary to preclude future instances of non-co-operation, putting political pressure on states through the ASP is likely to encourage discussion on consistent interpretation of measures that cannot be subjected to increasingly politicized partisan law and policies. ${ }^{157}$ For instance, greater support of co-ordination by the ICC in assisting states with those witnesses could increasingly reduce states' reluctance to co-operate with the ICC and could be the right price the ICC must pay to call detained witnesses to testify. Thus, it does not follow that the ICC should not be encouraged to follow this route. On the contrary, it shows that pursuing a common international legal framework for the issue of undesirable and unreturnable witnesses might be the right path to guarantee adequate protection for detained witnesses.

\section{Conclusions}

The ICC's fight against impunity is founded upon the guarantee of effective implementation of human rights. However, with the DRC Three we have seen the Court struggle to respect its human rights obligations from the Rome Statute or its status as an international organization.

This article used the plight of these detained witnesses to highlight a lacuna in the witness protection scheme enshrined in the Rome Statute. It argues that, contrary to the position stated in existing literature and the ICC's case law, Article 21(3) should be utilized as a 'generative power' to provide context and expand the scope of witness protection under Article 68 beyond a strict, literal interpretation. In the case of the DRC Three, this provision could, and should, have been applied to protect them from potential human rights violations from the DRC authorities. Despite assertions by the Court that it was unable to evaluate broader risks, this analysis was the de facto

\footnotetext{
${ }^{152}$ ICC, Summary Report of the Round Table on the Protection of Victims and Witnesses Appearing Before the International Criminal Court, 29 and 30 January 2009, at 5-7 available at www.icc-cpi.int/NR/rdonlyres/19869519-923D4F67-A61F-35F78E424C68/280579/Report_ENG.pdf. See also Cantor et al., supra note 18.

${ }^{153}$ S. Rosenberger, 'Navigating the Representative-Politics-Liberal-Rights Dilemma: Social Policy Designs for Nonremoved Migrants', (2019) 17 Journal of Immigrant \& Refugee Studies 1, at 11-26.

${ }^{154}$ S. Spencer, 'Postcode lottery for Europe's undocumented children. Unravelling an uneven geography of entitlements in the European Union', (2016) 60 American Behavioral Scientist 13, at 1613-28.

${ }^{155} \mathrm{~J}$. van Wijk, supra note 6 , at $182-3$.

${ }^{156}$ W. Schabas, An Introduction to the International Criminal Court (2007), at 252.

${ }^{157}$ Kress and Prost, supra note 149, at 1530; S. W. Kayuni 'The ICC's witness protection measures through the lens of policy-oriented jurisprudence', (2015) 4 UCL Journal of Law and Jurisprudence 2, at 271-98.
} 
effect of the compromise ultimately reached, as ICC observers were assigned to monitor the domestic treatment and trial of the witnesses on their return to the DRC.

This article also established that the ICC, as an international organization, has an autonomous responsibility to protect witnesses from non-refoulement arising under international customary law. It explained that the ICC's decision not to implement this obligation (owing to its own lack of territory) might have arisen from a conflation of the practicalities arising from non-refoulement with the humanitarian protection regime (which can only apply to states and not international organizations). In any event, it is debatable whether the ICC employed all reasonable steps to prevent witnesses from being refouled, since the ICC's lack of power to compel a third-party state to accept an individual is insufficient to meet the due diligence threshold.

Having analysed the ICC's obligations under international human rights law, this article critiqued existing proposals to ameliorate the lacuna, including revision of procedural rules to permit a witness to provide evidence in their own state of residence, and/or strengthen the ICC's co-operation with its host state. While the article recognizes that the ICC could follow the onerous route of 'diplomatic assurances' or revise its policy according to which the ICC chooses witnesses to testify, it proposes that the existing witness protection program should be strengthened by concluding new ad hoc agreements with member states and/or amending existing ones. The article argues that this solution guarantees witnesses the same level of protection available for refugees under Article 1 of the Convention and its Protocol relating to the Status of Refugees. Plus, it is already in use in circumstances where the ICC's own lack of territory risks undermining the Court's functioning. Thus, this solution may encourage witnesses to seek stronger protection via the ICC rather than pursuing unchartered waters of asylum applications. However, successful implementation would require co-operation with member states under different circumstances. First, it is necessary to evaluate whether the Refugee Convention provisions could apply to those individuals suspected of committing a crime against peace, a war crime, or a crime against humanity, undertake extra-territorial criminal prosecution of unreturnable individuals in their new country, and deal with those aliens once they served their sentence. This solution might encounter resistance from states parties because they are unwilling or illequipped to deal with undesirable and unreturnable witnesses.

The final part of this article framed the ICC's debate on undesirable and unreturnable witnesses within a wider debate since these aliens are generally caught in a legal limbo without long-term solutions. The predicament of how foreign national prisoners should be treated by a state (that seeks to both punish and/or deport them) is a fast-developing area of law and policy. Against this background, the ICC can work as a privileged diplomatic forum to develop a better approach for protecting undesirable and unreturnable witnesses. Although onerous for the ICC, this prominent role is justified by the very same necessity of the Office of the Prosecutor to call detained witnesses to testify, and by the ICC's inability to violate witnesses' rights once their testimony is over. While the ICC's special nature and co-operation system cannot be applied to situations outside its legal and political scope, this institution can encourage states to create a comprehensive, co-ordinated, and long-term solution to the quandary of undesirable and unreturnable aliens. Furthermore, the ICC can act as a super partes arbiter that balances competing interests. Solving the uncertainty surrounding witnesses' fate after their testimony could also benefit the relationship between individuals, (sending and receiving states, and international criminal law institutions to increase their mutual trust.

Cite this article: Pulvirenti R (2022). Undesirable and unreturnable individuals: Rethinking the International Criminal Court's human rights obligations towards detained witnesses. Leiden Journal of International Law 35, 433-451. https:// doi.org/10.1017/S0922156522000139 